\title{
Aerobic and Zumba Influences for the Upper Arm, Thigh and Waist Size on Mother's Bugar Pancing Medan Club in 2016
}

\author{
Eva Faridah \\ Faculty of Sport Sciences, Medan State University, Indonesia
}

\begin{abstract}
Exercise is an important element to maintain our health. Diet and exercise can help you lose weight. Body fat levels can be said as a comparison between fatty tissue in the body with body components that are free of fat. losing weight can be done by doing sports, because with sports activities, work done can be measured and regulated, and with measurable and regular work is expected and use energy derived from fat that is in the muscle cell tissue. One way to overcome obesity requires an activity that can burn fat. One of them is gymnastics, namely aerobic exercise and zumba gymnastics. The population in this study were participants of gymnastics Bugar Pancing Medan Club which amounted to 110 people. Samples in this study were taken 58 people. Dependent variable: result of change of circumference of upper, thigh, and waist. Variable free: a. Aerobic aerobics, b. Zumba Gymnastics. Based on the results of the research above that there is influence of exercise results between aerobic exercise with zumba exercises on changes in the size of the upper arm circumference, thigh circumference and waist circumference at the mothers of gymnastics members Bugar Pancing Medan Club in 2016.
\end{abstract}

Keywords: Aerobic, Zumba Exercises, Thighs and Waist

\section{Introduction}

In the era of globalization and along with the advancement of an increasingly advanced era, the development of technology has grown rapidly both in the field of agriculture, industry or in the health sector. These technological advances have created a variety of sophisticated equipment capable of lightening human work, for example is a washing machine and a water pump machine. Completeness of these tools make people lazy to move. People prefer to use elevators and escalators rather than up and down stairs. Tools - the results of these technological developments to make the work that was originally felt heavy and require a lot of energy to be light and easy to work because it occurs energy savings. The excess energy is stored under the skin called the fat when it is accumulated high, then the human will become fat, and if the total amount of fat in the body is enlarged then human will be overweight (Lynee Brick, 2002: 5). One way to overcome weight gain and body fat due to unbalanced calories, an effective program to control is to determine the balance between the incoming energy and the energy that comes out. (Lynee Brick, 2002: 59)

Obesity or obesity occurs due to the lack of balance between energy intake or intake with energy out which is used for activities or for daily activities. Obesity has an impact on human beings both positive and negative impacts. Most people assume that the fat person of his life is prosperous and all-sufficient to increase the prestige of the person. The negative impact of obesity is the emergence of various serious diseases, such as Hypertension or High Blood, Diabetes Mellitus or Diabetes and Heart Disease (Lynee Brick, 2002: 59). These problems make people think how to cope so as not to overweight.

According to Sadoso Sumosardjono (Yan, 2000: 25) a sports fitness expert explains how to overcome obesity in the best healthy is to set the diet along with exercise in the form of a combination of weight training and aerobics. Diet and exercise can help you lose weight. body fat levels can be said as a comparison between fatty tissue in the body with fat-free body components (scoot and Edward, 2009: 387), simply this fat accumulation occurs because the calories consumed body is greater than the calories burned the body, to increase the burning of the body and prevent excessive fat accumulation, we should be able to adjust the incoming calories and calories burned to balance. Exercise is an important ingredient for maintaining our health, because with the sport our body moves to burn all the calories in the body and keep our body function and this will be maximal if done with proper intake of food and pattern of rest.

At this time the sports are often done quite a lot of variations, ranging from morning walks, jogging, aerobics aerobic, nature tourism, swimming, futsal (Indonesian Sport), tennis, sports in fitness training (Fitness) and others, all sports that people do the goal to maintain health and on the other hand for fun, some kind of gymnastics that is growing and the current favorite is zumba, this gymnast is very fun to do and this gymnastics also increase the pulse in doing so, zumba done for 60 minutes and average burning happened to be high enough to see his movement fast enough. Zumba exercises combine many types of dance moves with the accompaniment of Latin music, this gymnast is useful to lower body fat levels, train cardiorespiratory, muscle strength, endurance, flexibility and balance and this gymnastics can be done by various age groups. Zumba gymnastics, this gymnastics much use muscle contraction especially in abdominal muscle, this gymnast can increase abdominal muscle strength because of contraction, movement in this gymnastics is not as fast as movement in zumba gymnastics because this gymnast try to contract muscle maximal, gym body done for 60 minute, this exercise can reduce fat in the body and increase muscle strength, endurance, flexibility and balance. 


\section{International Journal of Science and Research (IJSR) \\ ISSN (Online): 2319-7064}

Index Copernicus Value (2016): 79.57 | Impact Factor (2015): 6.391

One of the benefits of gymnastics is lowering the upper arm, thighs and waist, which is one of the biomotor components that becomes an important factor in adjusting for any kind of activity by stretching the broad body effectively without injury.

\section{Theoritical Review}

\section{Body Fat Level}

Fatty tissue contains triglycerides, phospholipids, and cholesterol, each gram contains quite a lot of calories. The fat is a group of organic bonds consisting of Carbon (C), Hydrogen $(\mathrm{H})$ and Oxygen $(\mathrm{O} 2)$ elements, which have a soluble property in certain solvent (fat solvent) substances such as petroleum benzene, ether. Fats in the body function for power reserves, bearing certain body organs, provide fixation of organs such as eyelids and kidneys, insulation so that body heat not much out, defend the body from external interference such as punch or harmful materials such as substances chemicals that can damage muscle tissue and provide good body lines (Janne Fonda, 1985: 89). The fat in our body consists of triglycerides, fatty acids and cholesterol (Andry Hartono, 2001: 91).

\section{Weight}

Thanks to the advancement of science and human technology can create sophisticated tools and equipment for various activities, so that in life there is a variety of facilities available. This causes people to perform activities effectively and efficiently (Slamet Prawiro Hartono, 1987: 94). The problem that occurs with the weight in a person is when someone is overweight. While the definition of obesity itself according to Katch (1990: 134) is the total amount of fat in the body is excessive or too much.

\section{Sports and Physical Activity}

According to Sadoso Sumosardjuno (2000: 42), losing weight can be done by doing sports, because with sports activities, work can be measured and regulated, and with measurable and regular work is expected and use energy derived from fat in the network muscle cells. According Sadoso Sumosardjuno (2001: 34) a health expert states the most effective exercise for weight loss is aerobic, such as roads, swimming, cycling and gymnastics.

\section{Aerobic Gymnastics}

One way to overcome obesity requires an activity that is able to burn fat. One of them is a gymnastics exercise that uses music that makes the activity of motion in doing gymnastics become more spirit so that feelings of the heart also come happy and happy. Sports gymnastics especially aerobic exercise is an activity that is done more than 30 minutes and done repeatedly and continuously. In an exercise of one hour or more, there will be a fat burning used for activities approaching $90 \%$ of the total amount of fat stored in the body, if exercised continuously (Katch 1990: 10). According to Berty Tilarso an aerobic instructor and expert fitness, one form of exercise is good because in addition to fun, the intensity of the exercise is done with exercise zone, the duration between 30-45 minutes and the frequency of exercise approximately between 2-3 days a week is enough to raise with little by little cardiovascular function and health and muscle endurance in a better state.
Indonesia has various types of gymnastics created by the government such as physical fitness exercises (SKJ), Healthy Gymnastics and so on. One alternative form is the dances that are combined with the rhythmic gymnastics movement, which is mostly done in gymnastics.

\section{Zumba gymnastics}

Zumba is one of the most popular gyms around the world, zumba was created in 2001 and then developed, since 2012 zumba became a worldwide trend, and this gym is used more than 185 countries in various parts of the world, zumba is one aerobic exercise accompanied by music. The thick latin music is combined with the salsa, regge, cha-cha, belly dance, flamenco, hip-hop, tango and samba rhythms. Initially zumba created by fitness fitness trainer Alberto Perez, Alberto has been active as an instructor since 1990, and one day when he was training he forgot to bring a tape for his gym class, so he improvised with the salsa music in his car. Alberto coached the class with the music he improvised on his own and found a good response where everyone who attended the class liked him.

Zumba gymnastics performed without standard rules, this type of gymnastics is to make the exercise as enjoyable as possible by doing movements that match the rhythm of music. Zumba gymnastics is different from other aerobic exercises, where focusing on reps but focusing on how to enjoy music and moves, to reduce body fat levels is recommended for at least 40 minutes, and this exercise is interspersed with periods of rest. Zumba gymnastics is done through several stages of exercise, which starts with warming, core and cooling exercises, all the steps are guided by the instructor and the participants follow the movements that the instructor exhibits.

\section{Research Method}

\section{A. Population}

\section{Population Research}

Population is the whole object that is the focus of research and a place to generalize the research findings (Sudjana: 1994: 180). The population in this study were participants gymnastic Bugar Pancing Medan Club which amounted to 110 people.

\section{Samples and Sampling Techniques}

The sample in this study was taken 58 people from the total population of 110 people. This study requires two groups then performed the initial test that measures the circumference of the upper arm, thighs, and waist, the initial test results are done matching by way of ordinal pairing.

\section{Variables}

Dependent variable: result of change of circumference of upper, thigh, and waist.

The independent variables: a. Aerobic aerobics, b. Zumba Gymnastics.

\section{Research Result}

From the group of gymnastics members of Bugar Pancing Medan Club, with data processed using t-test, the results are like the table below; 


\section{International Journal of Science and Research (IJSR) \\ ISSN (Online): 2319-7064}

Index Copernicus Value (2016): 79.57 | Impact Factor (2015): 6.391

Table 1: Results of Pre Test and Post Test.

\begin{tabular}{|c|c|c|c|c|}
\hline Group & \multicolumn{2}{|c|}{ Average } & Change & $\begin{array}{c}\text { Percentage of } \\
\text { Change }\end{array}$ \\
\cline { 2 - 3 } & Pre test & Post test & & $1,14 \%$ \\
\hline Experiment & 239,62 & 236,93 & 2,69 & $0,38 \%$ \\
\hline Control & 239,24 & 238,33 & 0,91 & 0,33 \\
\hline
\end{tabular}

Table 2: Differences of the upper arm, thigh, and waist size on mother's Bugar Pancing Medan Club

\begin{tabular}{|l|l|l|l|l|}
\hline Group & Mean & $\mathrm{t}$ count & $\mathrm{t}$ table 5\% & Explanation \\
\hline Experiment & 236,96 & 2,851 & 2,048 & Significant \\
\cline { 1 - 2 } Control & 238,33 & & & \\
\hline
\end{tabular}

\section{Discussion}

Based on the results of the research above that there is influence of exercise result between aerobic exercise with zumba gymnastics to change the size of upper arm circumference, thigh circumference and waist circumference on the mothers of gymnastics member Bugar Pancing Medan Club in 2016

\section{Conclusions and Suggestions}

Based on the data obtained from the data research results and statistical calculations t-test can be concluded as follows:

1) Aerobic exercise exercises and zumba gymnastics have an effect on the size change of upper arm, thighs and waist for the mothers of participants as well as gymnastics Bugar Pancing Medan Club.

2) The experimental group who were given aerobic exercise training experienced better upper arm, thigh and waist circumference changes compared to the control group who were trained in zumba exercise on mothers of gymnastics members of Bugar Pancing Medan Club.

\section{Suggestion}

1) All members of gymnastics gymnastic Field Pancing Medan Club are expected to be more diligent in carrying out gymnastics exercises, aerobic exercise, zumba exercises to change the size of the upper arm, thigh and waist circumference better and effectively formed according to the desired body shape.

2) The results of this study can be used as comparative material for similar studies.

\section{References}

[1] Andry Hartono. 2001. Kunci Diet dan Ramping Secara Efektif. Intisari Mediatama, Jakarta.

[2] Frank I. Katch, William D. Mc. Ardle. 1990. Nutrition Weight Control and Exercise. Philadelphia. Lea\&Febiger.

[3] Brick, Lynne. 2002. Bugar dengan Senam Aerobik. PT Raja Grafindo Persada, Jakarta.

[4] Fonda, Janne. 1985. Ramping Bersama Janne Fonda. PT Gaya Favorit Press, Jakarta.

[5] Sadoso Sumosardjuno. 2000. Manfaat Olahraga Bagi Wanita dalam Simposium Olahraga untuk Wanita. Yogyakarta.
[6] Sadoso Sumosardjuno. 2001. Sehat dan Bugar Petunjuk Praktis Berolahraga Yang Benar. Gramedia; Jakarta.

[7] Scott K. Powers, dan Edward T. Howley. 2009. Exercise physiology: theory and application to fitness and performance seventh edition. New York, McGrawHill Companies.

[8] Slamet Prawiro Hartono, Nawangsari Sugiri, Siti Sutarmi. 1987. Buku Pelajaran SMA. Biologi. Jakarta. Erlangga.

[9] Sudjana. 1994. Desain dan Analisis Eksperimen, Bandung: Tarsito, Edisi III.

[10] Yan. 2000. Tak Sulit Jadi Langsing. Jakarta. Intisari Mediatama.

Volume 6 Issue 12, December 2017

www.ijsr.net

Licensed Under Creative Commons Attribution CC BY 